\title{
HURRICANE RESILIENCE INDICATORS IN MEXICAN CARIBBEAN COASTAL CITIES
}

\author{
O. FRAUSTO ${ }^{1}$, A. VAZQUEZ ${ }^{1}$, L. ARROYO ${ }^{1}$, L. CASTILLO ${ }^{2} \&$ M.L. HERNÁNDEZ ${ }^{2}$ \\ ${ }^{1}$ Sustainable Development Division, Quintana Roo University, Mexico. \\ ${ }^{2}$ Science and Engineering Division, Quintana Roo University, Mexico.
}

\begin{abstract}
The use of indicators to prevent hurricane impacts locally is a new tool in the area of climate change and resilience. However, many critics the methods for designing these indicators, mainly those resulted from bottom-up and top-down models. Based on the social-ecological analysis, it is defined coastal urban resilience for hurricanes under the bottom-up and top-down model, with the support of experts and other key actors in the integral hurricane management in three coastal cities in the Mexican Caribbean: Chetumal, Tulum and Playa del Carmen. Thus, the objective of the present research is to generate coastal urban resilience indicators that comprehend the complex learning system, adaptation and selforganization in hurricanes. Indicators measures three spatial levels: local, regional and global and one temporal (1-year cohort of 1990). Besides, the following are the three dimensions of indicators: A. Resilience capacities (history of hurricane impacts). B. Consequences (management and self-organization). C. Learning and behaviors (in front of effects and damages).

Keywords: disasters prevention, monitoring, risk management, urban resilience.
\end{abstract}

\section{INTRODUCTION}

A crucial topic at the national level is the creation of public policies that make it possible to develop secure local communities. In terms of identifying national problems that inhibit growth and obstruct the welfare of inhabitants, a study on urban resilience in response to natural catastrophes is needed [1]. In addition, climate change, loss of biodiversity, economic crisis and extreme poverty are only some indicators that demonstrate the transformation of highly vulnerable socio-ecological systems with a low capacity for adaptation $[2,3]$.

The concept of resilience is used to approach socio-ecological systems. It center on a non-linear dynamic, thresholds, uncertainty, surprise, gradual change along with periods of rapid change, as well as its interaction on the scale of time and space [4]. Uncertainty and changes are characteristics of the ecological landscape and social organization, which is a factor for sustainability, and consequently, resilience is the capacity to face and adapt to challenges, as well the conservation of sources of innovation and renovation [5].

The use of the concept of resilience in the study of disasters has focused on the evaluation of natural dangers. Resilience is understood as the capacity of a community to re-establish itself after the impact of these disasters [6]. Gallopin suggests that resilience in response to disasters is the capacity of a community to recover. This is visualized as a process involving connections, relationships and interdependencies among the actors who form part of complex community systems, together with their capacities for adaptation [7].

The indicators are used as an effective management tool that makes it possible to evaluate diverse phenomena and processes. Consequently, the proposal is presented to design a system of resilience indicators in order to evaluate the response to hurricanes in coastal cities. 


\section{RESILIENCE COASTAL INDICATORS}

The multi-faceted concept of socio-ecological resilience is an approach involving interdisciplinary synthesis. The main characteristics are the capacity to maintain identity, continuity in space and time, memory, innovation and political/management decisions [8].

Folke argues that the resilience approach is centered on understanding the dynamic of socio-ecological systems, in which previously the explanation for an undertaking was given by a mathematical model, whereas now the social dimension is considered to understand these changes. This has permitted the inclusion of factors such as social learning and memory, mental models and the incorporation of knowledge in the system, the visualization and construction of scenarios, leadership, agents, social groups and networks, organizational and institutional apathy and changes, the capacity for adaptation, adaptation and transformation of the system of government that manages environmental services [9]. In addition, the factors of biodiversity, spatial heterogeneity, government and management structures, and ecological and social memory were also considered [10].

Disaster management requires several levels of government and an increase in the ability to deal with uncertainty and surprise by means of mobilizing different capacities for resilience [11]. As a result, it is important to recognize coastal ecosystems as the most affected and altered because across the world human populations are concentrated on the coast. To improve the resilience of these coastal systems, it is important to understand the relations between ecosystems and society, such that the monitoring and control of indicators are essential [12].

Therefore, by identifying the means of livelihood [13] applied to resilience, the factors can be understood as the context of vulnerability, assets, transformation structures and processes, strategies and achievements. Vulnerability refers to the external environment where communities survive and which cannot be controlled in the short or medium term. The means of livelihood of these communities and their assets are affected by critical trends (economic, technological, demographic growth, access to resources, policies, etc.), crises or extreme events (adverse meteorological conditions, natural threats, economics, conflicts, health, etc.) and the weather or seasonality (climate, prices, production, health, employment opportunities, etc.) [14].

In light of the foregoing, the conception and construction of indicators is based on two classic models: a) the institutional model (top-down) and b) the local agenda model (bottom-up) [15]. The indicator is considered as a sign, whether quantitative or qualitative, where the main characteristic is the fulfillment of well-defined objectives and goals [16]. Therefore, the system of indicators proposed in this article is based on the concept developed according to the local agenda model for coastal urban resilience after hurricanes.

\section{METHODS}

The characteristics of the places that will be analyzed are explained and then the method for developing the system of indicators is described.

\subsection{Places of study}

The cities of Playa del Carmen, Tulum and Chetumal are located in the eastern sector of the Yucatán Peninsula, in the Caribbean region of Mexico (Fig. 1).

These cities are located in coastal areas with lagoons and sand dunes, which is an indication of their highly dynamic geomorphologic and coastal processes. In accordance with the social and territorial characteristics and their economic predominance, this region is divided 


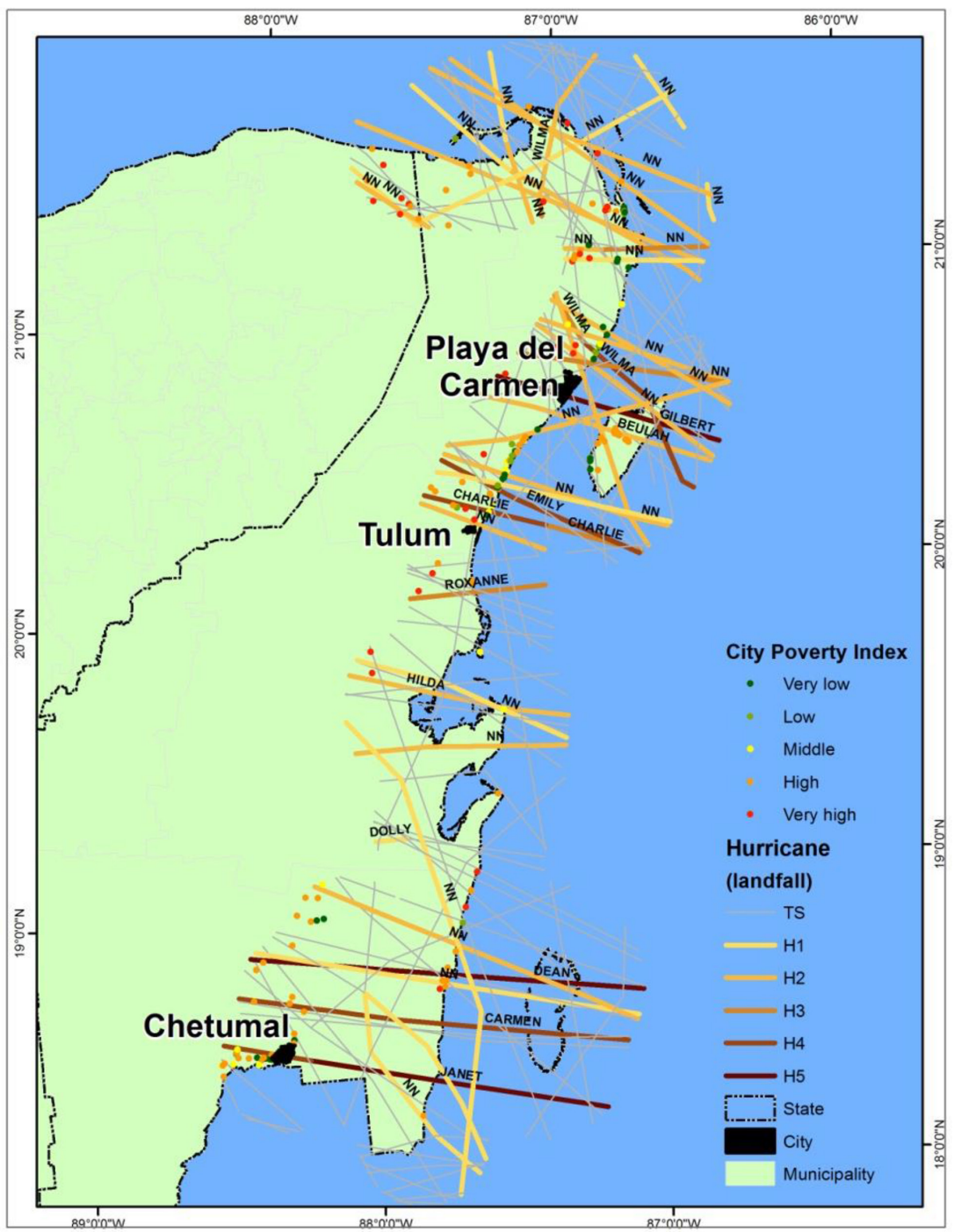

Figure 1: Location of the cities Playa del Carmen, Tulum and Chetumal in the Mexican Caribbean.

into three parts: the southern border, Mayan region and northern Caribbean region. The latter is the most dynamic in demographic and economic terms.

The cities of Chetumal, Tulum and Playa del Carmen are home to $24.1 \%$ of the state's population [17]. They are tourism destinations with pronounced economic, territorial and population transformations.

Chetumal, the capital of the state has a population of 151,243 inhabitants [18]. The town of Othón P. Blanco forms parts of the Hydrological Region of Yucatán, the closed basins and Chetumal Bay. The only rivers in the whole peninsula are located within its bounds: Río Hondo and Río Escondido. It has several lagoons, the most noteworthy of which are a portion 
of Laguna de Bacalar, Laguna Guerrero, Laguna Agua Salada, Laguna Chile Verde, Laguna Milagros and Laguna San Felipe.

Tulum, the town has a territory of 2,040.94 $\mathrm{km}^{2}$ and it makes up $4.9 \%$ of the state's surface area [19]. It forms part of the physiographic region of the Yucatán Peninsula and the geomorphological unit of the Caribbean plains. The topography of the area is flat and it does not go beyond $25 \mathrm{~m}$ of altitude [20]. The subsoil is hard limestone, which permits the filtration of rain, favoring the formation of underground rivers and sinkholes, some of which are used for tourism. There are some areas with soft limestone. This material gives the soil stability as a foundation. With these characteristics, agricultural uses are limited. This is not the case for urban development and tourism activity [21, 22].

Playa del Carmen. This municipality covers a surface area of $2205 \mathrm{~km}^{2}$. According to the 2010 census data [23], the population reaches 216,730 inhabitants, $4.33 \%$ of the state population, most of which live in the city of Playa del Carmen, followed by Puerto Aventuras. Within its territory, the municipality has 148 towns, of which 138 have a population of less than 100 inhabitants [24]. It is known as the main urban and tourism center in the Mayan Riviera. Since its early days as a fishing village until the present, it has been closely linked to its $80 \mathrm{~km}$ of coastline.

\subsection{Methodology}

The objective to create a system of resilience indicators for coastal cities has been carried out in three stages:

(a) Revision of the basic and historical information on the cities of Chetumal, Tulúm and Playa del Carmen, concentrating on the identification of historical antecedents and the impacts of hurricanes on the coasts of Quintana Roo.

(b) Two workshops with 20 local actors. The first workshop served to build a consensus around the concept of coastal urban resilience in response to hurricanes. In the second workshop, the participants identified the means of livelihood factors that determine the elements of the system of coastal urban resilience indicators. As a result, the system could be constructed. The workshops were held in January and February 2016.

(c) The development of the proposal for coastal urban resilience indicators in response to hurricanes and the presentation of the indicator tool developed.

\section{RESULTS}

The presentation of the results has been divided into two sections. The first section includes the conceptual proposal of coastal urban resilience in response to hurricanes. The second section addresses the system of indicators for monitoring and control.

\subsection{Coastal urban resilience in response to hurricanes}

The consensus at the forum held with local actors was that resilience in response to hurricanes in coastal cities should be defined as:

"The capacity that people, groups, and the coastal society and community have to recover from adversity and adapt to new conditions using their behavior and learning experiences to deal with the negative effects and destruction caused by floods, winds, rains, erosion, storm tides and, how they face their consequences, which may be: emotional, economic, familial, 
land or asset related, material and socio-ecological; and may also be on a spatial and temporal scale." [25].

According to this definition, the first key factors for the integration and collection of information in terms of space and time have been identified: a) living conditions of the people, groups, society or community; b) history of the adverse events and adaptations, behavior and learning experiences in response to these events; c) the destruction and negative impact of the main dangers; and d) actions taken to deal with the adversities.

Table 1: Systems of coastal urban resilience indicators for cities in the Mexican Caribbean.

\begin{tabular}{|c|c|c|}
\hline $\begin{array}{l}\text { Resilience in } \\
\text { coastal cities }\end{array}$ & Indicators & $\begin{array}{l}\text { Means of } \\
\text { livelihood }\end{array}$ \\
\hline \multirow[t]{3}{*}{ Living conditions } & $\begin{array}{l}\% \text { of employment } \\
\text { Index for quality of life } \\
\text { Rate of the reduction in the frequency or seriousness } \\
\text { of crises }\end{array}$ & $\begin{array}{l}\text { Employment } \\
\text { creation }\end{array}$ \\
\hline & $\begin{array}{l}\% \text { of increase in the levels of incomes among poor } \\
\text { populations } \\
\text { Index for changes in food security in households } \\
\% \text { improvement in basic needs (housing, health, } \\
\text { nutrition) } \\
\text { Rate of changes in income distribution and } \\
\text { reduction of inequality } \\
\text { Index for improvement in human rights }\end{array}$ & $\begin{array}{l}\text { Reduction of } \\
\text { poverty }\end{array}$ \\
\hline & $\begin{array}{l}\text { \# of financial, educational, housing and sanitation } \\
\text { services } \\
\text { Level of nutrition, } \\
\text { Literary rate, health } \\
\% \text { of loans for development } \\
\text { Rate of communications }\end{array}$ & $\begin{array}{l}\text { Welfare and } \\
\text { capacities }\end{array}$ \\
\hline $\begin{array}{l}\text { History of the } \\
\text { adverse events and } \\
\text { Destruction and } \\
\text { impact }\end{array}$ & $\begin{array}{l}\text { Preparation to face risks } \\
\text { Capacity to deal with, prepare for and adapt to } \\
\text { natural disasters or economic crises } \\
\text { Capacity to deal with, prepare for and adapt to } \\
\text { seasonality }\end{array}$ & $\begin{array}{l}\text { Adaptation, } \\
\text { recovery and } \\
\text { vulnerability }\end{array}$ \\
\hline $\begin{array}{l}\text { Actions taken to } \\
\text { deal with adversi- } \\
\text { ties }\end{array}$ & $\begin{array}{l}\text { Increase in environmental sustainability } \\
\text { Reduction of conflicts and increase in their resolu- } \\
\text { tion and peace } \\
\text { Changes in ways of life } \\
\text { Sustainability of activities } \\
\text { Sustainability of institutional changes } \\
\text { Sustainability of the reduction of poverty Permanent } \\
\text { elimination of social exclusion } \\
\text { Reduction of inequalities among disadvantaged } \\
\text { groups }\end{array}$ & $\begin{array}{l}\text { Sustainability } \\
\text { of resources }\end{array}$ \\
\hline
\end{tabular}




\subsection{Proposal for the system of indicators}

The key factors for the integration and collection of information are summarized in five categories or types of capital: human, social, natural, physical and financial. The structures and processes are linked to the public and private institutions that set the different guidelines, as well as the policies that seek to reach particular objectives. There are five achievements in the area of means of livelihood. They are related to means of livelihood and sustainability: (a) employment creation; (b) reduction of poverty among the monitoring indicators (levels of income and consumption, access to services, etc.); (c) welfare and capacities (going beyond material and food needs to include self-esteem, security, stress, power, exclusion, etc.); (d) adaptation, recovery and vulnerability; and (e) sustainability of basic resources. One of the main objectives of the theory of sustainable means of livelihood is to support villages so that they can increase their assets and became more resistant to vulnerability [26].

Within this outline, the indicators represented by the system of indicators for coastal urban resilience are identified in Table 1.

\subsection{Example of the coastal urban resilience indicator}

The coastal urban resilience indicators are shown according to their key elements. In this section, the indicators for poor households in the city of Playa del Carmen are demonstrated.

\subsubsection{Poor households}

Central theme: Living conditions/reduction of poverty

City: Playa del Carmen.

Scale and level of aggregation: Urban center - basic geostatistical area - household - people

Cohort: 2000 - 2005 - 2010

Name of indicator: Level of extreme poverty

Description: Percentage of homes with heads of the family (men and women) situated below the poverty line according to the local and national definition.

Urban resilience indicator of Poverty: Playa del Carmen, Mexico.

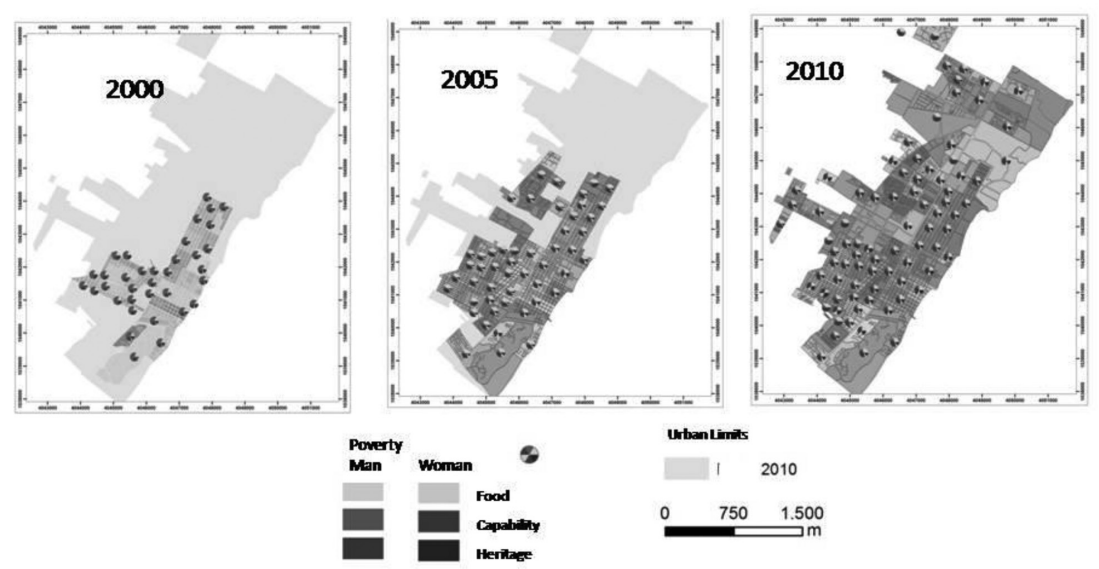

Figure 2: Poverty indicators in Playa del Carmen. 
Comments on resilience: In general terms, a household is poor when it presents notable shortages of food and basic needs such as clothing, footwear, housing, access to transport, among others. For members of households in these conditions, the possibility of improving their living conditions is reduced, as the surrounding environment restricts their capacity to build relations with the rest of society, which would allow them to access education and decent occupations, both of which are fundamental human rights. The risk of continued exclusion for people living in poverty makes it essential to identify them and slowly break with the vicious cycle in which they are trapped.

Methodology: The calculation of levels of poverty for the urban environment is used. It is divided into three levels [27].

Tools: Maps of poverty in the city of Playa del Carmen, years 2000 - 2005 - 2010 (Fig. 2).

\section{CONCLUSIONS}

Indicators have been used for more than six decades. This tool starts with a process of longterm planning; however, in this article, the diagnosis of welfare policies was first considered. Currently, the indicators for sustainable development have been identified as a basic tool for monitoring advances in the welfare of communities. Within the climate change and resilience paradigm, these indicators help to outline a vision for prevention and reduction of disasters and catastrophes.

Indicators are a useful tool for planning, monitoring and controlling the implementation of systems for the reduction of risks and disasters. In this article, the local proposal to address the resilience of coastal urban communities in the Mexican Caribbean is presented.

Based on the principle of local participation, resilience among coastal urban communities was defined, and using the elements of means of livelihood, 23 quantitative and qualitative indicators were identified for five areas and three conceptual factors.

The example of the indicator for poor households is given as a key component of coastal urban resilience in response to hurricanes to improve living conditions, deal with means of livelihood and reduce extreme poverty. The spatial disintegration in terms of people per Household in the city of Playa del Carmen is presented, with the cohort in the year 2000, monitoring in 2005, and control in 2010.

\section{ACKNOWLEDGEMENTS}

I would like to thank CONACYT Ciencia Básica for supporting the project "Resilience of coastal cities in the Mexican Caribbean in response to disasters caused by hurricanes: Chetumal, Tulum y Playa del Carmen". As well as REDESCLIM - RISAF - CONACYT for supporting the project "Water and extreme natural phenomena". And finally, CONACYT Posgrado de Calidad for the PhD scholarship awarded to the student Aidé Vazquez to develop research on integrated coastal and sustainability management in newly established villages in tourism areas.

\section{REFERENCES}

[1] Sánchez, Cavazos y Morales., Plan estratégico nacional para la prevención y reducción de los desastres asociados a eventos hidrometeorológicos y climáticos en México. (Chapter 4). Conviviendo con la Naturaleza, ed. T. Cavazos, ILSA, México, pp. 124 143,2015

[2] Pelling, M. \& Manuel-Navarrete, D., From resilience to transformation: the adaptive cycle in two Mexican urban centers. Ecology and Society, 16(2), p. 11, 2011. 
[3] Birkmann, J., Measuring Vulnerability to Natural Hazards: Towards Disasters, UN-University, Bonn, 2006.

[4] Folke, C., Resilience: the emergence of a perspective for social - ecological systems analyses. Global Environmental Change, 16(3), pp. 253-267, 2006. http://dx.doi.org/10.1016/j.gloenvcha.2006.04.002

[5] Lebel, L., Anderies, J., Campbell, B., Folke, C., Hatfield-Dodds, S., Hughes, T. \& Wilson, J., Governance and the capacity to manage resilience in regional social-ecological systems. Ecology and Society, 11(1), p. 19, 2006.

[6] Cutter, S., Buerton, C. \& Emrich, C., Disaster resilience indicators for benchmarking baseline conditions. Journal of Homeland Security and Emergency Management, 7(1), Article 51, 2010.

[7] Velázquez, D. \& Castillo, L., Sistemas complejos adaptativos, sistemas socio- ecológicos y resiliencia. Quivera, pp. 11-32, 2015.

[8] Cumming, S., Barnes, S., Schmink, M., Sieving, K., Southworth, J., Binford, M., Holt, R., Stickler, C. \& Van Holt, T., An exploratory framework for the empirical measurement of resilience. Ecosystems, 8(8), pp. 975-987, 2005. http://dx.doi.org/10.1007/s10021-005-0129-z

[9] Folke, C., Resilience: the emergence of a perspective for social-ecological systems analyses. Global Environmental Change, 16(3), pp. 253-267, 2006.

http://dx.doi.org/10.1016/j.gloenvcha.2006.04.002

[10] Adger, W.N., Hughes, T.P., Folke, C., Carpenter, S.R. \& Rockström, J., Social-ecological resilience to coastal disasters. Science, 309(5737), pp. 1036-1039, 2005. http://dx.doi.org/10.1126/science.1112122

[11] Frausto, O., Bases de datos georreferenciadas de fenómenos hidrometeoroloógicos extremos en la península de Yucatán, UQROO - REDESCLIM - CONACYT, p. 120, 2013.

[12] Chambers, R. \& Conway, G., Sustainable Rural Livelihoods: Practical Concepts for the 21st Century, IDS Discussion Paper, 1992.

[13] Elliot, J., Desarrollo rural en Cajamarca. Aplicación del enfoque de medios de vida sostenibles, Soluciones Prácticas-ITDG, Lima, Perú, 2008.

[14] Walker, B.H., Gunderson, L.H., Kinzig, A.P., Folke, C., Carpenter, S.R. \& Schultz, L., A handful of heuristics and some propositions for understanding resilience in socialecological systems. Ecology and Society, 11(1), p. 13, 2006.

[15] Frausto, O., Rojas, J. \& Santos, X., Indicadores de Desarrollo Sostenible a Nivel Regional y Local: Análisis de Galicia, España, y Cozumel, México.(Capitulo V). Estudios Multidisciplinarios en Turismo, ed. R. Guevara, Secretaria de Turismo, México, pp. 110-134, 2005.

[16] Frausto, O., Chale, G. \& Rojas, J., Herramientas y técnicas para la aplicación y evaluación de indicadores de desarrollo sustentable para localidades y municipios. Turismo: Teoría y Praxis, ed. A. Palafox, Plaza y Valdez, México, pp. 85-97, 2005.

[17] PNUMA, Perspectivas del Medio Ambiente Urbano: GEO Playa del Carmen. Programa de las Naciones Unidas para el Medio Ambiente (PNUMA), H. Ayuntamiento de Solidaridad y Planeta Limpio A.C. 259: 2008.

[18] Rojas, J., Frausto, O., Tun, J. e Ihl, T. Las metas del milenio (saneamiento mejorado y acceso a agua potable) en Cozumel y Playa del Carmen, México. Teoría y praxis Universidad de Quintana Roo, México, 12, pp. 10-33, 2012.

[19] INEGI, Encuesta intercensal 2015, Instituto Nacional de Estadística Geografía e Informática, México, 2015. 
[20] INEGI, Censo de Población y Vivienda, 2010, Instituto Nacional de Estadística Geografía e Informática, México, 2010.

[21] Sánchez, W., Alcances de la cultura turística en Tulum, Solidaridad, Quintana Roo, tesis de maestría en Ciencias Sociales aplicada a los estudios regionales, Universidad de Quintana Roo, México, 2006.

[22] Gobierno Municipal de Solidaridad, 2007.

[23] INEGI, Encuesta Intercensal 2015,Instituto Nacional de Estadística Geografía e Informática, México, 2015.

[24] Zamudio, J., Tulum: su camino como nuevo municipio, tesis de licenciatura en Sistemas Comerciales, Universidad de Quintana Roo, México, 2009.

[25] Castillo, L., Memoria técnica del primer reporte del proyectode ciencia básica CONACYT, México, Mayo de 2016.

[26] Scoones, I., Sustainable Rural Livelihoods: A Framework for Analysis, Institute of Development Studies.IDS Working Paper 72, 1998.

[27] Frausto, O. y Welch G., M. Indicators of the Habitat Agenda in Mexico: Local urban observatory programme. Journal of US-China Public Administration, 7(11), pp. 39-45, 2010. 